\title{
Velvet pad surface sampling of anaerobic and aerobic bacteria: an in vitro laboratory model
}

\author{
DENNIS RAAHAVE, ALICE FRIIS-MØLLER
}

From the Department of Clinical Microbiology (Statens Seruminstitute) and the Department of Gastroenterological Surgery, Bispebjerg Hospital, Copenhagen, Denmark

SUMMARY Velvet pads have been evaluated in an experimental, laboratory model, simulating intraoperative sampling of Staphylococcus epidermidis, Escherichia coli and Bacterioides fragilis. After sampling, the pad was placed in a transport medium and kept in an anaerobic atmosphere, before being shaken and rinsed, followed by anaerobic and aerobic culture. This technique permitted quantitatively high recoveries of the test bacteria. Velvet pad sampling could be a measure to determine the density of aerobic and anaerobic bacteria during operation in an effort to predict the risk of postoperative wound sepsis.

Different types of wounds—-for example, the open (traumatic) wound, the burn wound, a graft bed or the operative incision represent different problems in sampling for quantitative bacteriological culture. This laboratory has had an interest in following in particular the course of the operation wound. ${ }^{12}$ Postoperative wound infections are initiated primarily during operation as a result of contamination with bacteria from different sources. ${ }^{3-5}$ However, relatively few investigators have obtained quantitative cultures from the operative incision. ${ }^{6-10}$ For this purpose Raahave ${ }^{2}$ has used velvet pads, since areas rather than volumes (biopsies) should be sampled, because no deeper penetration by bacteria can have occurred at that time. ${ }^{11}$

It is widely recognised today that anaerobic organisms, especially Bacteroides fragilis are implicated in many wound infections. ${ }^{491012} \mathrm{We}$ therefore found it of great interest to investigate whether anaerobic bacteria, in analogy with aerobic, could be sampled quantitatively by velvet pads. An experimental laboratory model was used, mimicking sampling from operation wounds. We studied the influence of the different test bacteria, transport medium, detergent and centrifugation.

\section{Material and methods}

VELVET PADS

Pale, boiled-out velvet with a close-knit pile was cut into strips of $2.0 \times 4.5 \mathrm{~cm}$ and the back was glued to aluminium foil with a water- and heat-resistant contact adhesive. ${ }^{213}$ The foil extending at both ends? allowed the pad to be handled without touching the velvet itself. The pads were heat-sterilised, and were moistened in $0.9 \%$ sterile $\mathrm{NaCl}$ immediately before use.

ORGANISMS

Three strains were used: Staph epidermidis (CCM 2434), $B$ fragilis and $E$ coli.

\section{MEDIA}

The test plates contained an agar medium with $5 \%$ defibrinated horse blood, $0.35 \%$ glucose, $0.001 \%$ fatty acids $\mathrm{C}_{12-18^{\prime}} 0.8 \% \mathrm{Na}_{2} \mathrm{HPO}_{4} .12 \mathrm{H}_{2} \mathrm{O}, 0.67 \%$ $\mathrm{KCl}, 0 \cdot 25 \% \mathrm{Nz}$-amine type B (Sheffield Chemicals) and $0 \cdot 125$ yeast hydrolysate (Orthana). The plates were prereduced before use. The transport media were sterile $0.9 \% \mathrm{NaCl}$ or peptonewater (peptone Orthana $40 \mathrm{~g}, \mathrm{NaCl} 5 \mathrm{~g}$ and distilled $\mathrm{H}_{2} \mathrm{O}$ to $100 \mathrm{ml}$ with $2 \mathrm{~g}$ glucose and $10 \mathrm{ml} 5 \%$ Liquoid Roche added after autoclaving).

\section{SAMPLING PROCEDURES}

Experiments were carried out by a standardised procedure (Fig. 1). Test suspensions were prepared from overnight serum broth cultures (except $B$ fragilis: $48 \mathrm{~h}$ ) by diluting with serum to $1 / 10^{-4}$. The blood agar surface was flooded with $1 \mathrm{ml}$ of bacterial suspension and excess liquid was removed by a Pasteur pipette. When visible moisture had disappeared, a sterile velvet pad was applied firmly to 


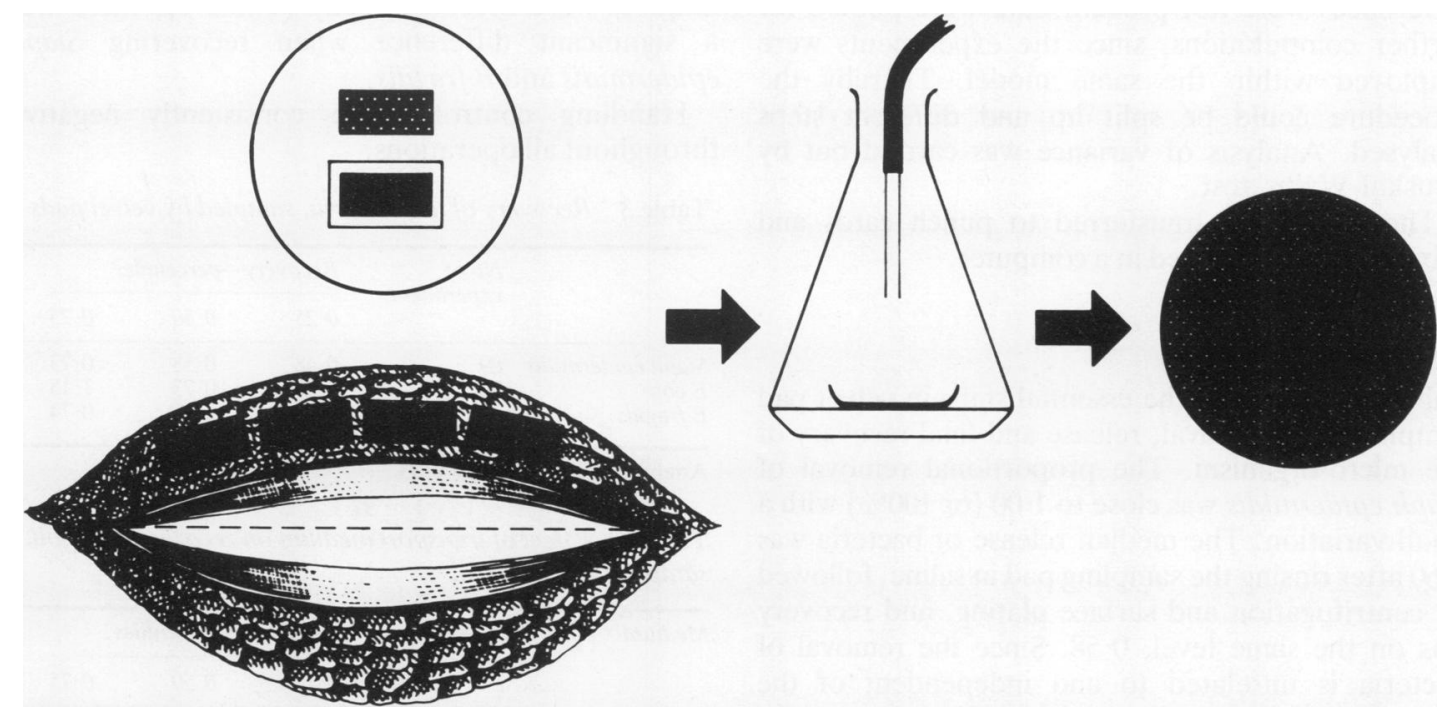

Fig. 1 The experimental laboratory model, mimicking sampling of bacteria from operation wounds by velvet pads.

the inoculated test surface with an even pressure for 2-3 s. Sterile gloves were worn. After sampling, the velvet pad was transferred to a $250 \mathrm{ml}$ Erlenmeyer flask containing $10 \mathrm{ml}$ sterile transport medium. In the experiments with $B$ fragilis carbon dioxide was led into the flask through a Pasteur pipette, after which the flask was capped with a cotton plug and aluminium foil. The flask with its contents was agitated in a Gallenkamp shaker for $10 \mathrm{~min}$, after which the fluid was centrifuged at $3000 \mathrm{rpm}$ for $30 \mathrm{~min}$ (Sorvall). The supernatant was removed and the deposit was spread on the plates and incubated aerobically and anaerobic. In some experiments centrifugation was not done, but aliquots of $1 \mathrm{ml}$ were spread directly after shaking.

The detergents tested were Triton X-100, $0.1 \%$ and Tween-80, $0.5 \%$.

In all experiments, control of sterilisation and contamination was carried out by taking velvet pads through all procedures except for the sampling step.

\section{COUNTING AND CALCULATIONS}

The following counts (Abacus counter) were made (i) control colony forming units (CFU), $\mathrm{N}_{0}$, through a template with an aperture the size of one pad (Fig. 1) (ii) residual CFU, $R_{1}$, at the site of velvet pad sampling (Fig. 2) and (iii) final CFU, I, from the final spread. Removal, release and recovery efficiencies were calculated by using the following equations:

$$
\text { Removal }=\frac{N_{0}-R_{1}}{N_{0}}
$$

$$
\begin{aligned}
& \text { Release }=\frac{I}{N_{0}-R_{1}} \\
& \text { Recovery }=\frac{N_{0}-R_{1}}{N_{0}} \times \frac{I}{N_{0}-R_{1}}=\frac{I}{N_{0}}
\end{aligned}
$$

Distribution-free statistical terms were used. Calculations were carried out at first within the experiments. Wilcoxon's test (paired data) and Mann-Whitney's test (unpaired data) were used ${ }^{14}$ to examine the significance of differences. Where

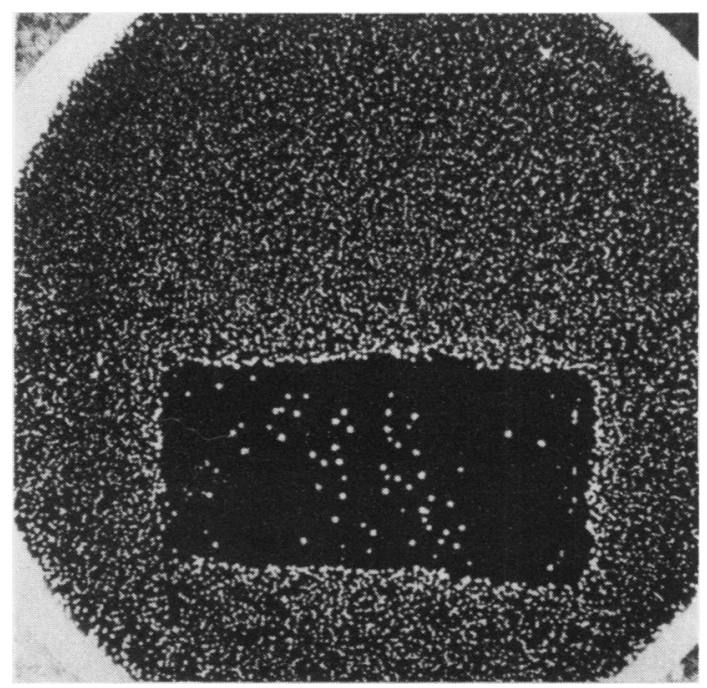

Fig. 2 Residual colonies of $B$ fragilis after velvet pad sampling and subsequent anaerobic incubation. 
differences were not proven, data were pooled for further computations, since the experiments were employed within the same model. Thereby the procedure could be split up and different steps analysed. Analysis of variance was carried out by Kruskal-Wallis' test.

The data were transferred to punch cards and subsequently processed in a computer.

\section{Results}

Table 1 summarises the essential steps in velvet pad sampling: the removal, release and final recovery of the micro-organism. The proportional removal of Staph epidermidis was close to 1.00 (or $100 \%$ ) with a small variation. The median release of bacteria was 0.60 after rinsing the sampling pad in saline, followed by centrifugation and surface plating, and recovery was on the same level, 0.58 . Since the removal of bacteria is unrelated to and independent of the procedures following removal (as also seen from the formula), median removals $(0.91$ to 0.96$)$ have been compared for different bacteria in Table 2. The pooled value was 0.95 and no significant differences were found. In contrast, significant differences were seen in final recoveries of the test bacteria (Table 3 ).

The recovery of $E$ coli after rinsing the pad in saline or in peptonewater is compared in Table 4; no significant differences were found.

The effect of adding a detergent to the transport medium is shown in Table 5. There was an equal and significant rise in recovery of Staph epidermidis when Tween-80 and Triton X-100 were added to saline.

Whereas the recovery of $E$ coli did not differ significantly when centrifugation took place or $1 \mathrm{ml}$

Table 1 Removal, release and recovery of Staph epidermidis after velvet pad sampling

\begin{tabular}{lllll}
\hline & \multirow{2}{*}{$\begin{array}{l}\text { No of } \\
\text { experiments }\end{array}$} & \multicolumn{3}{l}{ Percentiles } \\
\cline { 3 - 5 } & & 0.25 & 0.50 & 0.75 \\
\hline Removal & 89 & 0.93 & 0.96 & 0.98 \\
Release & 89 & 0.50 & 0.60 & 0.78 \\
Recovery & 89 & 0.48 & 0.58 & 0.73 \\
\hline
\end{tabular}

Table 2 Proportional removal of test bacteria after sampling with velvet pads

\begin{tabular}{lrlll}
\hline & \multirow{2}{*}{$\begin{array}{l}\text { No of } \\
\text { experiments }\end{array}$} & \multicolumn{3}{l}{ Proportional removal } \\
\cline { 3 - 5 } & & 0.25 & 0.50 & 0.75 \\
\hline Staph epidermidis & 133 & 0.94 & 0.96 & 0.97 \\
E coli & 70 & 0.91 & 0.96 & 1.00 \\
B fragilis & 40 & 0.86 & 0.91 & 0.93 \\
Total & 255 & 0.91 & 0.95 & 0.97 \\
\hline
\end{tabular}

Analysis of variance: $p>0.05$ (Kruskal-Wallis test). aliquots were spread directly (Table 6), there was a significant difference when recovering Staph epidermidis and $B$ fragilis.

Handling controls were consistently negative throughout all operations.

Table 3 Recovery of test bacteria, sampled by velvet pads

\begin{tabular}{|c|c|c|c|c|}
\hline & \multirow{2}{*}{$\begin{array}{l}\text { No of } \\
\text { experiments }\end{array}$} & \multicolumn{3}{|c|}{ Recovery percentiles } \\
\hline & & 0.25 & 0.50 & 0.75 \\
\hline $\begin{array}{l}\text { Staph epidermidis } \\
\text { E coli } \\
B \text { fragilis }\end{array}$ & $\begin{array}{l}89 \\
30 \\
20\end{array}$ & $\begin{array}{l}0 \cdot 48 \\
0 \cdot 39 \\
0 \cdot 30\end{array}$ & $\begin{array}{l}0.58 \\
0.73 \\
0.48\end{array}$ & $\begin{array}{l}0 \cdot 73 \\
1 \cdot 15 \\
0 \cdot 74\end{array}$ \\
\hline
\end{tabular}

Analysis of variance: $\mathrm{p}<0.05$.

Table 4 Effect of transport medium on recovery of E coli, sampled by velvet pads

\begin{tabular}{lllll}
\hline Medium & $\begin{array}{l}\text { No of } \\
\text { experiments }\end{array}$ & \multicolumn{3}{l}{ Recovery-percentiles } \\
\cline { 2 - 5 } & & 0.25 & 0.50 & 0.75 \\
\hline Saline & 30 & 0.39 & 0.73 & 1.15 \\
Peptonewater & 20 & 0.23 & 0.75 & 1.41 \\
\hline
\end{tabular}

Mann-Whitney test: $p>0.05$.

Table 5 Effect of detergent on recovery of Staph epidermidis, sampled by velvet pads and subsequently rinsed

\begin{tabular}{lllll}
\hline & $\begin{array}{l}\text { No of } \\
\text { experiments }\end{array}$ & \multicolumn{3}{l}{ Recovery-percentiles } \\
\cline { 3 - 5 } & & 0.25 & 0.50 & 0.75 \\
\hline No detergent & 15 & 0.34 & 0.47 & 0.52 \\
Triton X-100 & 15 & 0.52 & 0.79 & $0.98^{*} \dagger$ \\
Tween-80 & 15 & 0.71 & 0.80 & $0.99^{*} \dagger$
\end{tabular}

${ }^{*} p<0.01$, as compared to no detergent (Wilcoxon test).

$+\mathrm{p}>0.05$ (Wilcoxon test).

Table 6 Effect of centrifugation on recovery of Staph epidermidis, $E$ coli and $B$ fragilis, sampled by velvet pads

\begin{tabular}{|c|c|c|c|c|}
\hline & \multirow{2}{*}{$\begin{array}{l}\text { No of } \\
\text { experiments }\end{array}$} & \multicolumn{3}{|c|}{ Recovery-percentiles } \\
\hline & & 0.25 & 0.50 & 0.75 \\
\hline $\begin{array}{l}\text { Centrifugation } \\
\text { Staph epidermidis } \\
\text { E coli } \\
\text { B fragilis }\end{array}$ & $\begin{array}{l}15 \\
20 \\
20\end{array}$ & $\begin{array}{l}0 \cdot 68 \\
0 \cdot 23 \\
0 \cdot 30\end{array}$ & $\begin{array}{l}0.80 \\
0.75 \\
0.48\end{array}$ & $\begin{array}{l}1 \cdot 04^{*} \\
1 \cdot 41 \dagger \\
0 \cdot 74 \ddagger\end{array}$ \\
\hline $\begin{array}{l}\text { No centrifugation } \\
\text { Staph epidermidis } \\
\text { E coli } \\
B \text { fragilis }\end{array}$ & $\begin{array}{l}15 \\
19 \\
20\end{array}$ & $\begin{array}{l}1 \cdot 12 \\
0 \cdot 46 \\
1 \cdot 06\end{array}$ & $\begin{array}{l}1 \cdot 27 \\
0 \cdot 85 \\
1 \cdot 65\end{array}$ & $\begin{array}{l}1 \cdot 65 \\
1 \cdot 54 \\
2 \cdot 20\end{array}$ \\
\hline
\end{tabular}

Centrifugation $v$ no centrifugation.

${ }^{*} \mathrm{p}<0.01$, as compared to no centrifugation (Wilcoxon test).

tp $>0.05$, as compared to no centrifugation (Mann-Whitney test).

$\ddagger \mathrm{p}<0.01$, as compared to no centrifugation (Mann-Whitney test).

\section{Discussion}

Blood agar plates were freshly seeded with aerobic and/or anaerobic bacterial cells, mimicking an 
operation wound contaminated with bacteria. Escherichia coli, $B$ fragilis and a staphylococcus species were chosen as test bacteria, since these organisms are important pathogens in postoperative wound infections. ${ }^{134912}$ A uniform finding was the very effective removal of bacteria, from 91 to $96 \%$. This is in contrast to the results by Lederberg and Lederberg, ${ }^{15}$ who found that only 10 to $30 \%$ of the initial cells were taken up by the velvet. It seems that the type of velvet used here greatly facilitates the removal of bacteria, irrespective of species, probably because of adhesive forces. In order to release the bacteria the velvet pad was shaken and rinsed in the medium. In experiments with cotton swabs, rinse techniques have similarly been shown release enhancing. ${ }^{1617}$

Several studies have shown that avoiding desiccation of bacteria after sampling seems much more important than the type of transport medium used, if bacteria are to survive. ${ }^{18-20}$ As the aim was to extend the method to clinical use only two media were compared, sodium chloride and peptonewater, and no difference was found between the high recoveries. It was also shown that a detergent could further improve the recovery rate, probably due to an enhanced release of bacteria from the sampling velvet pad.

When we started the experiments anaerobiosis was not produced during the initial sampling step, except for rendering the flask oxygen-free by flushing with carbon dioxide. ${ }^{21}{ }^{22}$ However, the aerotolerance offor example $B$ fragilis, seems relatively high, as shown by equal recovery rates, even after a six-hour exposure to oxidised fluid. ${ }^{23}$ Finally, centrifugation and resuspension of the sediment followed by surface plating were compared to a more simple manoeuvre of spreading $1 \mathrm{ml}$ aliquots directly onto the agar plates. The recovery rates of $E$ coli did not differ significantly. However, incorporating centrifugation seems to lower the recovery of $B$ fragilis, perhaps because of aggregation of bacterial cells. On the other hand, plating $1 \mathrm{ml}$ aliquots, the recoveries exceed the optimal $1 \cdot 00$.

There are no elaborate methods to determine adequately the true number of bacteria in the operation wound. Swabs have been used widely, but are inadequate to indicate the true degree of contamination. ${ }^{52-26}$ While burn and traumatic wounds have been sampled by impression gauze ${ }^{27}$ or by homogenised tissue samples ${ }^{28}$ these methods have apparently not been used for operation wounds. However, quantitative sampling of such wounds has until recently been done also by irrigation procedures. $^{6910}$ Clearly, there is a need for quantitative methods to measure the degree of contamination, not only manifest infection. We think, that velvet pad sampling could probably contribute to fill this gap.

We wish to thank the Legacy of Carl and Ellen Herz for a research grant to this study and the National Research Council for Medical Sciences for providing a research technician. We should also like to thank J Nyboe, statistician, for his advice and help.

\section{References}

' Raahave D. Effect of plastic skin and wound drapes on the density of bacteria in operation wounds. Br J Surg 1976;63:421-6.

${ }^{2}$ Raahave D. New technique for quantitative bacteriological sampling of wounds by velvet pads: clinical sampling trial. J Clin Microbiol 1975;2:277-80.

${ }^{3}$ Davidson AIG, Clark C, Smith G. Postoperative wound infection: a computer analysis. Br J Surg 1971;58:333-7.

${ }^{4}$ Leigh DA. Wound infections due to Bacteroides fragilis following intestinal surgery. Br J Surg 1975;62:375-8.

${ }^{5}$ Broete L, Gillquist J, Taernvik A. Wound infections in general surgery. Acta Chir Scand 1976;142:99-106.

${ }^{6}$ Lilly HA, Lowbury EJL, London PS, Porter MF. Effects of adhesive drapes on contamination of operation wounds. Lancet 1970;ii:431-2.

' Mcllrath DC, van Heerden JA, Edis AJ, Dozois RR. Closure of abdominal incisions with subcutaneous catheters. Surgery 1976;80:411-6.

${ }^{8}$ Magee C, Hanry B, Rodeheaver G, Fox J, Edgerton MT, Edlich RF. A rapid technic for quantitating wound bacterial count. Am J Surg 1977;133:760-2.

9 Bartlett JG, Condon RE, Gorbach SL, Clarke J, Nichols RL, Ochi S. Impact of oral antibiotic regimen on colonic flora, wound irrigation cultures and bacteriology of septic complications. Ann Surg 1978;188:249-54.

${ }^{10}$ Scheibel JH, Nielsen ML, Wamberg T. Septic complications in colorectal surgery after 24 hours versus 60 hours of preoperative antibiotic bowel preparation. Acta Chir Scand 1978;144:527-32.

"Saymen DG, Nathan P, Holder IA, Hill EO, McMillan BG. Infected surface wound: an experimental model and a method for the quantitation of bacteria in infected tissue. Appl Microbiol 1972;23:509-14.

12 Sanderson PJ, Wren MWD, Baldwin WF. Anaerobic organisms in postoperative wounds. J Clin Pathol 1979;32:143-7.

${ }^{13}$ Holt RJ. Aerobic bacterial counts on human skin after bathing. $J$ Med Microbiol 1971;4:319-27.

14 Bradley JV. Distribution-free statistical tests. Englewood Cliffs: Prentice-Hall, 1968.

is Lederberg J, Lederberg E. Replica plating and indirect selection of bacterial mutants. J Bacteriol 1952;63:399-406.

${ }^{16}$ Angelotti R, Foter MJ, Busch KA, Lewis KH. A comparative evaluation of methods for determining the bacterial contamination of surfaces. Food Res 1958;23:175-85.

${ }^{17}$ Nystroem PO. The microbiological swab sampler-a quantitative experimental investigation. Acta Pathol Microbiol Scand $[B]$ 1978;86:361-7.

${ }^{18}$ King WL, Hurst A. A note on the survival of some bacteria in different diluents. J Appl Bacteriol 1963;26:504-6.

${ }^{19}$ Pettit F, Lowbury EJL. Survival of wound pathogens under different environmental conditions. J Hyg (Camb) 1968;66:393406.

${ }^{20}$ Christian DL, Ederer GM. Evaluation of bacteriological transport medium. Am J Med Technol 1973;39:12-6.

${ }^{21}$ Holdemann LV, Moore WEC. Anaerobe laboratory manual. Virginia Polytechnique Institute and State University: Blacksburg, 1977. 
${ }^{22}$ Gargan RA, Phillips I. A comparison of three methods for the transport of clinical specimens containing anaerobes. Med Lab Sci 1979;36:159-69.

${ }^{23}$ Spengler MD, Rodeheaver GT, Edlich RF. Practical technique for quantitating anaerobic bacteria in tissue specimens. J Clin Microbiol 1979;10:331-3.

${ }^{24}$ Peach S, Hayek $L$. The isolation of anaerobic bacteria from wound swabs. J Clin Pathol 1974;27:578-82.

${ }^{25}$ Kelly M, Warren RE. The value of an operative wound swab sent in transport medium in the prediction of later clinical wound infection: a controlled clinical and bacteriological evaluation. $\mathrm{Br}$ J Surg 1978;65:81-8.
${ }^{26}$ Collee JG. Factors contributing to loss of anaerobic bacteria in transit from the patient to the laboratory. Infect 1980;suppl 2:145-7.

${ }^{27}$ Brentano L, Gravens DL. A method for the quantitation of bacteria in burn wounds. Appl Microbiol 1967;15:670-1.

${ }^{28}$ Robson MC, Bogart JN, Heggers JP. An endogenous source for wound infection based on quantitative bacteriology of the biliary tract. Surgery 1970;68:471-6.

Requests for reprints to: Dr Dennis Raahave, Anemoneve 24, 2970 Hørshølm, Denmark. 